\title{
Peranan Pembelajaran Agama Islam dalam Pembentukan Karakter Religius dan Toleransi Siswa Sekolah Dasar
}

\author{
Nurdin $^{1}$, Muhammad Toto Nugroho ${ }^{2}$ \\ ${ }^{1}$ Sekolah Dasar 59 Tanjung Jabung Barat, Jambi, Indonesia \\ ${ }^{2}$ Pendidikan Guru Sekolah Dasar, Universitas Jambi, Jambi, Indonesia
}

\begin{tabular}{l}
\hline \hline Article Info \\
\hline Article history: \\
Received Mar 6, 2020 \\
Revised Mei 2, 2020 \\
Accepted Jul 6, 2020 \\
\hline
\end{tabular}

\section{Keywords:}

Agama Islam

Pendidikan Karakter

Sekolah Dasar

\begin{abstract}
ABSTRAK
Tujuan penelitian: Tujuan dari penelitian ini adalah untuk mendeskripsikan peranan Pembelajaran Agama Islam dalam membentuk karakterk peserta didik yang religious dan toleransi di Sekolah Dasar.
\end{abstract}

Metodologi: Penelitian ini menggunakan jenis penelitian deskriptif kualitatif, dimana sumber data yang diperoleh dari kegiatan observasi, wawancara, dan dokumentasi. Teknik analisis data yang digunakan menggunakan pendekatan penelitian kualitatif dimulai dari pengumpulan data, merduksi data, penyajian data dan penarikan kesimpulan.

Temuan utama: Peranan pembelajaran Agama Islam dalam membentuk karakter religius dan toleransi pada diri peserta didik di SDN 59/V Bram Itam yaitu menerapkan membiasakan berdoa sebelum melakukan kegiatan belajar, mengucapkan salam, serta pembelajaran seperti membaca surah yasin setiap hari jum'at, hafalan surah-surah pendek dan doa sehari-hari.

Keterbaruan penelitian: Bahwa pe,nelajaran agama di sekolah dasar memiliki keterkaitan dengan pembentukan karakter yang baik pada siswa.

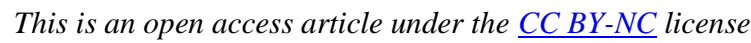

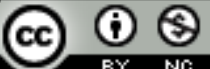

\section{Corresponding Author:}

Muhammad Toto Nugroho,

Fakultas Keguruan dan Ilmu Pendidikan, Universitas Jambi, Jambi, Indonesia

Jl. Lintas Tungkal-Jambi, Kec. Bram Itam, Kab. Tanjung Jabung barat, Jambi

Email: muhammadtotonugroho@gmail.com

\section{PENDAHULUAN}

Pendidikan karakter adalah suatu sistem penanaman nilai-nilai karakter kepada warga sekolah yang meliputi komponen pengetahuan, kesadaran atau kemauan dan tindakan untuk melaksanakan nilai-nilai tersebut [1].Pendidikan karakter bukan berupa materi yang dapat dihafal serta tidak dapat dilakukan evaluasi dalam rentang waktu yang pendek. Pendidikan karakter merupakan pendidikan yang teraktualisasikan dalam segala aspek kegiatan peserta didik baik dilingkungan sekolah maupun diluar sekolah. Karena dalam pelaksanaan pendidikan karakter tidak terlepas dari fungsi dan tujuan pendidikan nasional yaitu salah satunya berfungsi untuk mengembangkan kemampuan dan membentuk watak serta peradaban bangsa yang bermatabat.Character education is a conscious effort that is done to form learners into positive and noble personality according to the competency standards of graduates (SKL) so that it can be implemented in everyday life [2]. Pendidikan karakter merupakan upaya sadar yang dilakukan untuk membentuk peserta didik menjadi positif dan berkepribadian luhur sesuai standar kompetensi lulusan (SKL) sehingga dapat diimplementasikan dalam kehidupan sehari-hari.

Karakter dalam islam yaitu (Akhlaque al-hasana): dalam bahasa arab, karakter berasal dari kata "akhlaque" yang artinya kepribadian, sifat, perilaku, disposisi, pandangan, dan lain-lain [3], Akhlak adalah buah dari akidah dan syari'ah yang benar [4]. Karakter merupakan bagaimana cara berfikir dan berperilaku 
yan menjadi ciri khas seorang individu untuk hidup, bekerjasama, baik dalam keluarga, masyarakat hingga bernegara. Seorang individu yang memiliki karakter yang baik, akan memiliki pengetahuan yang luas mengenai potensi dalam dirinya, seperti percaya diri, logis, kreatif, jujur, bertanggung jawab, dan sebagainya. Pendidikan karakter bertujuan menciptakan seseorang agar memiliki kerendahan hati, memiliki keberanian (courage) dalam arti mereka benar-benar punya keberanian menegakkan sesuatu yang dianggap benar dan bertanggung jawab, serta tidak memiliki keraguan [5].

Permasalahan yang dihadapi saat ini adalah hilangnya karakter dari para peserta didik yang meliputi hilangnya sikap saling menghargai dari peserta didik, saling peduli antar peserta didik hingga moral dan sikap menghormati di kalangan peserta didik mulai pudar. Dengan permasalahan tersebut dibutuhkan peran serta dari setiap pendidik maupun tenaga kependidikan yang ada di lingkungan sekolah dasar untuk membimbing peserta didik khususnya pada jenjang sekolah dasar. Pendidikan karakter mempunyai makna bagaimana menanamkan kebiasaan mengenai hal-hal yang baik dalam kehidupan sehingga anak memiliki kesadaran dan pemahaman yang tinggi serta kepedulian dan komitmen untuk menerapkan hal-hal yang baik tersebut dalam kehidupan sehari-harinya. Penanaman nilai karakter tersebut dapat diupayakan melalui mata pelajaran yang ada di sekolah dasar.

Salah satu mata pelajaran yang memiliki keterakaitan yang erat dangan karakter adalah Pendidikan Agama Islam. Mata pelajaran Pendidikan Agama Islam merupakan salah satu sarana yang mampu untuk memberikan konstribusi dalam penanaman nilai karakter, pembentuk karakter yang sesuai dengan ajaran dan norma yang ada. Mata pelajaran Pendidikan Agama Islam (PAI) merupakan salah satu mata pelajaran yang di dalamnya mencakup pelajaran memahami, menghayati dan juga mengamalkan materi yang diajarkan dalam kehidupan sehari-hari [6]. Karena itu lah Pendidikan Agama Islam diharapakan dapart menanamkan hingga mengembangkan karakter yang baik bagi peserta didik di sekolah dasar.

Pendidikan Agama Islam dalam pengimplementasiannya sangat kental dengan nilai-nilai karakter dan akhlak baik itu sesama manusia maupun kepada Tuhan Yang Maha Esa. Karena hal ini lah Pendidikan Agama Islam yang ada di sekolah dasar harus dijalan dengan semaksimalnya guna untuk membentuk karakter yang religious, yang mana mampu untuk peserta didik berhubungan dengan baik kepada Tuhan serta berinterkasi dengan sesama. Nilai religius adalah suatu kepatuhan seseorang dalam melaksanakan agama yang dianutnya, toleran dan selalu hidup rukun dengan penganut agama lain [7]. Perilaku tersebut mencerminkan nilai-nilai karakter yang religious, jika karakter religius tertanam dalam diri peserta didik, maka setiap tingkah laku hingga tutur katanya tidak akan melanggar norma-norma yang ada.

Pemebelajaran Agama Islam di sekolah dasar pada hakikatnya tidak hanya mengajarkan tentang nilai-nilai religus saja akan tetapi mengajarakan nilai yang berdasarkan nilai yang terkandung dalam pancasila salah satunya karakter toleransi. Pendidikan Agama Islam dapat memenanamkan karakterk religius pada peserta didik dikarenakan, karakter toleransi berkaitan dengan karakter religius. Nilai religius merupakan suatu nilai utama yang wajib ditanamkan kepada setiap peserta didik sebagai penunjang keselamatan dan kebahagiaan, di dunia dan di akhirat [8]. Karakter toleransi yang dimiliki seseorang tercermin bagaimana ia mampu untuk berbuhungan dengan baik kepada sesama, menghormati, saling menghargai, dan peduli antar sesama tidak memandang latar belakang orang lain.

Pada hakikatnya pendidikan bertujuan untuk menjadikan sesorang menguasai sebuah konsep dan mampu untuk mengimplemtasikan demi kepentingan bersama. Proses pendidikan tersebut menjadikan manusia dapat menemukan potensi ataupun mengembangkan potensi dirinya serta mengaktualisasikan kemampuan yang ada pada dirinya [9]. Untuk itu sangat penting bagi Pendidikan Agama Islam dalam menanamkan prilaku peserta didik yang mencerminkan karakter religius dan toleransi, hal ini tidak hanya menjadi kewajiban guru Pendidikan Agama Islam tetapi juga setiap pendidik, tenaga pendidik, orang tua maupun masyarakat dilingkungan sekitar sekolah dasar. Peran yang dilakukan dengan baik oleh keluarga, sekolah maupun masyarakat dalam pendidikan,akan memberi peluang besar mewujudkan sumber daya manusia terdidik yang bermutu [10]. Penanaman nilai karakter pada anak usia sekolah dasar menjadikan anak paham bagaimana untuk memposisikan diri mereka di lingkungan sosial serta dalam kehidupan sosial setiap individu membutuhkan orang lain.

Berdasarkan pemaparparan yang telah dijelaskan, peneliti tertarik untuk melakukan penelitian di SD 59/V Bram Itam dengan topik peranan Pendidikan Agama Islam dalam pembentukan karakter religius dan toleransi siswa sekolah dasar.

\section{METODE PENELITIAN}

Penelitian ini menggunakan jenis penelitian deskriptif kualitatif yang menjabarkan sebuah peristiwa yang ada di sekolah dasar. Penelitian ini dilaksanakan di SD Negeri 59/V Bram Itam pada semester ganjil tahun ajaran 2020/2021. Sasaran dalam penelitian ini adalah peneliti ingin mengetahui bagaimana peranan Pendidikan Agama Islam dalam pembentukan karakter religius dan toleransi. Dikarenakan adanya pandemi 
maka penelitian menggunakan instrumen sebagai berikut: (1). Wawancara, kegiatan ini dilakukan secara mendalam, dan (2) Dokumentasi, penelitian menggunakan dokumen berupa foto-foto yang berkaitan dengan topik penelitian. Teknik analisis data yang digunakan dalam penelitian ini terdiri dari pengumpulan data, reduksi data, penyajian data dan penarikan kesimpulan.

\section{HASIL DAN PEMBAHASAN}

\subsection{Hasil}

3.1.1 Pendidikan Agama Islam dalam Pembentukan Karakter Religius dan Toleransi

Agama merupakan hal yang sangat urgen dalam kehidupan, baik itu anak-anak, remaja, dewasa ataupun orang tua., apabila seseorang tidak memahami ajaran agama dengan baik, maka tak heran jika perbuatan dan perilakunya sangat jauh dari dikatakan baik [11]. Pendidikan Agama Islam memiliki peran yang penting dalam pembentukan karakter peserta didik, pembentukan tersebut haruslah dengan kolaborasi dari berbagai pihak diantarannya, orang tua, guru, kepala sekolah hingga masyakarat. Pendidikan Agama Islam bersifat fungsional, terpakai sepanjang hayat manusia, semakin bertambah umur seseorang, semakin dirasakan olehnya kebutuhan dan keperluan akan agama [12].

Pembentukan karakter peserta didik tidak hanya diilakukan dengan bentuk pembelajaran saja, akan tetapi perlu dilakukan dengan pembiasan baik dilingkungan sekolah maupumenn luar sekolah yang dapat dilakukan melalui Pendidikan Agama Islam. Oleh karena ini, Pendidikan Agama Islam mampu membentuk karkater peserta didik yang toleransi dan religius, yang selanjutnya akan tercermin di kehidupan peserta didik sehari-hari. Pembentukan karakter religius peserta didik dapat dilakukan dengan cara meningkatkan keimanan, ketaqwaan peserta didik terhadap kerpercayaan agama yang dianutnya. Pendidikan Agama Islam dimaksudkan untuk peningkatan potensi spiritual dan membentuk peserta didik agar menjadi manusia yang beriman dan bertakwa kepada Tuhan Yang Maha Esa [13]. Pembentukan karakter religius melalui kegiatan keagamaan dapat dilaksanakan di seklah dasar bisa diadakan dengan hal yang sederhana.

Berdasarkan hasil wawancara bersama narasumber guru SDN 59/V Bram itam, mengemukakan bahwa cara pembentukan karakter religius pada diri peserta didik dapat dilakukan denga berbagai cara, diantaranya membiasakan berdoa sebelum melakukan kegiatan belajar, mengucapkan salam, serta pembelajaran seperti membaca surah yasin setiap hari jum'at, hafalan surah-surah pendek dan doa seharihari. Pendidikan Agama Islam berperan dalam pembetukan karakter peserta didik terceminkan dengan kegiatan, berdoa, mengucapkan salam, kegiatan membaca yasin bersama, membiasakan untuk tidak mencontek, dan menghafalkan doa sehari-hari.

Berdasarkan hasil wawancara bersama guru SDN 59/V Bram Itam, mengatakan bahwa cara pembentukan karakter toleransi pada peserta didik di sekolah dasar dapat dilakukan melalui proses pembelajaran maupun diluar jam pembelajaran Pendidikan Agama Islam yang waktunya terbatas. Ada beberapa nilai karakter toleransi diantaranya, menghargai, bersaudara, kerjasama, tolong-menolong, berbagi. Hal ini dapat dilakukan dengan cara mengadakan kelompok belajar yang terdiri dari peserta didik yang berbeda latar belakang, menanamkan pemahaman serta contoh yang nyata toleransi antar sesama, melakukan kegiatan gotong royong, saling menghormati, saling berbagi.

\subsection{Pembahasan}

Untuk menumbuhkan nilai-nilai toleransi dan religius bukanlah hal yang mudah bagi guru, dalam hal ini seluruh guru di sekolah bekerja sama agar terciptanya suasana yang harmonis [14]. Pembentukan karakter dapat dilakukan pada peserta didik di sekolah dasar, karena dalam tahap ini perkembangan sikap serta kognitif manusia lebih mudah untuk dibentuk. Sehingga sangat penting untuk membentuk sikap religius dan toleransi pada diri peserta didik saat usia sekolah dasar, dan salah satu upaya nya dapat dilakukan melalui Pendidikan Agama Islam. Pendidikan agama Islam adalah upaya membimbing, mengarahkan, dan membina pesrta didik yang dilakukan secara sadar dan terencana agar terbina suatu kepribadian yang utama sesuai dengan nilai-nilai ajaran agama Isalm [15].

Pada hakikatnya, semua mata pelajaran yang ada di sekolah dasar mampu untuk membentuk karakter yang baik bagi perkembangan peserta didik. Keberhasilan Pendidikan Agama Islam dalam membentuk karakter peserta didik, tidak terlepas dari pemilihan stratergi dan metode yang tepat dalam proses kegiatan belajar mengajar yang ada di sekolah dasar. Dari hasil yang didapati, guru di SDN 59/V Bram Itam menerapkan berbagai metode pembelajaran yang bevariasi diantaranyam metode diskusi, metode tanya jawab, metode demonstrasi dan metode ceramah. Selain pemahaman terhadap peserta didik, guru-guru juga membrikan contoh yang nyata dengan memperlihatkan karakter religus dan toleransi.

Berdasarkan hasil penelitian peranan Pendidikan Agama Islam dalam pembentukan karakter religius dan toleransi begitu kuat dan berarti, karena tidak hanya dalam proses pembelajaran melainkan juga diluar 
proses pembelajaran. Peranan Pendidikan Agama Islam dalam pembentukan karakter peserta didik di SDN 59/V Bram Itam yaitu sebagai berikut.

a. Berdoa Sebelum Melakukan Kegiatan: Berdasarkan hasil wawancara bersama guru, peserta didik selalu diarahkan untuk membaca doa setiap hendak melakukan kegiatan maupun setelah melaksanakan kegiatan dengan kepercayaan mereka masing-masing.

b. Membaca Surah Yasin Bersama: Setiap hari jumat, peserta didik yang beragama islam rutin untuk melaksanakan membaca yasin bersama di lingkungan sekolah yang dipimpin oleh guru, setelah membaca yasin peserta didik diberikan penguatan karakter melalui arahan/ceramah yang diberikan oleh guru.

c. Mengahafalkan Doa Sehari-Hari: Dari jenjang kelas 1 peserta didik sudah dituntun untuk menghafalkan doa sehari-hari, hal ini bertujuan agar setiap kegiatan yang dilakukan peserta didik dapat berkah dari Tuhan Yang Maha Esa

d. Membiasakan Tidak Mencontek: Peserta didik di SDN 59/V Bram Itam tidak diperbolehkan mencontek/kerjasama saat melakukan kegiatan ulangan harian maupun ketika ujian berlangsung. Berdasarkan wawancara guru meskipun begitu ada beberapa peserta didik yang ketahuan mencontek teman mereka.

e. Mengafalkan Surah Surah Pendek: Berdasarkan wawancara, guru membimbing para peserta didik untuk menghafalkan surah-surah pendek, selanjutnya disetorkan kepada guru Pendidikan Agama Islam dan ditinjau bagaimana hafalan surah mereka.

Membentuk karakter toleransi dalam diri peserta didik usia sekolah dasar telah di implementasikan dalam kegiatan pembelajaran maupun diluar jam pembelajaran Pendidikan Agama Islam, dimana berdasarkan hasil wawancara bersama guru peserta didik mampu untuk mencerminkan karakter toleransi diantara keberagaman baik suku, budaya, bahasa serta agama yang ada dalam diri para peserta didik. Hal ini dicerminkan dengan sikap peserta didik yang mau untuk menolong tanpa melihat latar belakang, mau bekerjasama dalam kelompok belajar maupun saat kegiatan gotong royong yang diadakan sekolah, saling menghormati satu sama lain, mau berbagi bersama teman-teman, serta tidak memilih-milih teman artinya mereka mau berteman dengan siapa saja.

Berdasarkan pemaparan yang telah dijelaskan maka Pendidikan Agama Islam yang ada di SDN 59/V Bram Itam telah mampu berperan memebentuk karakter religius dan toleransi pada diri peserta didik, yang tecerminkan dengan perilaku peserta didik yang ada. Peranan Pendidikan Agama Islam dalam pembentukan karakter religius dan toleransi yang ada di sekolah tersebut telah sesuai dengan ajaran dan aqidah islamiah. Diharapkan Pendidikan Agama Islam yang ada mampu untuk membentuk generasi yang berkualitas tidak hanya dalam segi kognitif saja tetapi dalam juga dalam segi karakter.

\section{KESIMPULAN}

Peranan pembelajaran Agama Islam dalam membentuk karakter religius dan toleransi pada diri peserta didik di SDN 59/V Bram Itam yaitu menerapkan membiasakan berdoa sebelum melakukan kegiatan belajar, mengucapkan salam, serta pembelajaran seperti membaca surah yasin setiap hari jum'at, hafalan surah-surah pendek dan doa sehari-hari. Sedangkan peranan pembelajaran Agama Islam dalam membentuk karakter religius dan toleransi pada diri peserta didik yaitu dengan mengadakan kelompok belajar yang terdiri dari peserta didik yang berbeda latar belakang, menanamkan pemahaman serta contoh yang nyata toleransi antar sesama, melakukan kegiatan gotong royong, saling menghormati, saling berbagi.

\section{UCAPAN TERIMA KASIH}

Penulis sangat berterimakasih kepada pihak Sekolah Dasar Negeri 59/V Bram Itam yang telah membantu penelitian ini, dan semua pihak yang telah berkontribusi kepada penulis dalam penulisan penelitian ini.

\section{REFERENSI}

[1] Rachmadyanti, P. Penguatan pendidikan karakter bagi siswa sekolah dasar melalui kearifan lokal. JPsd (Jurnal Pendidikan Sekolah Dasar), vol. 3, no. 2, pp. 201-214, 2017.

[2] Amini, Syamsuyurnita, \& Hasnidar. "The Development of Character Education Model Trough an Integrated Curriculum at Elementary Education Level in Medan City," IJLRES - International Journal on Language, Research and Education Studies, vol. 1, no. 2, pp. 298-311, 2017.

[3] Aladdiin, H. M. F., dan PS, A. M. B. K, "Peran Materi Pendidikan Agama Islam di Sekolah dalam Membentuk Karakter Kebangsaan," Jurnal Penelitian Medan Agama, vol. 10, no. 2, 2019. 
[4] Amin, A., Zulkarnain, S., dan Astuti, S. "Implementasi Pendidikan Agama Islam Berwawasan Lingkungan Hidup Dan Budaya Di Sekolah Menengah Pertama," Indonesian Journal of Social Science Education (IJSSE), vol. 1, no. 1, pp. 96-113, 2019.

[5] Tanis, H. "Pentingnya Pendidikan Character Building dalam Membentuk Kepribadian Mahasiswa. Humaniora, vol. 4, no. 2, pp. 1212-1219, 2013.

[6] Syamsuri, S. "Penggunaan metode STAD untuk meningkatan motivasi belajar siswa pada mata pelajaran pendidikan agama islam," Jurnal Pendidikan Agama Islam Indonesia, vol. 1, no. 1, pp. 1-8, 2020.

[7] Majid, A., dan Handayani, D. "Pendidikan Karakter Prspektif Islam,” Bandung: PT Remaja Rosda Karya, 2011.

[8] Mukhliso, M. "Strategi guru pendidikan agama Islam untuk menanamkan pendidikan karakter religius di sekolah dasar," Jurnal Pendidikan Agama Islam Indonesia, vol. 1, no. 1, pp. 64-68, 2020.

[9] Desmawan, W. A., dan Nugroho, G. "Identifikasi karakter disiplin siswa Madrasah Tsanawiyah Syifa'ul Qulub pada mata pelajaran akidah akhlak," Jurnal Pendidikan Agama Islam Indonesia, vol. 1, no. 1, pp. 23-27, 2020.

[10] Amin, A. "Sinergisitas Pendidikan Keluarga, Sekolah Dan Masyarakat; Analisis Tripusat Pendidikan," At-Ta'lim: Media Informasi Pendidikan Islam, vol. 16, no. 1, pp. 106-125, 2018.

[11] Alimni, A. Penerapan pendekatan deepdialogue and critical thingking (dd\&ct) untuk meningkatkan mutu proses dan hasil belajar pai siswa kelas viii smpn 20 kota bengkulu. Annizom, vol. 2, no. 2, 2017.

[12] Amin, A. "Metode \& Model Pembelajaran Agama Islam,” Bengkulu: IAIN Bengkkulu Pers, 2015.

[13] Sanusi, H. P. "Peran Guru PAI dalam Pengembangan Nuansa Religius di Sekolah," Jurnal Pendidikan Agama Islam-Ta'lim, vol. 11, no. 2, pp. 143-153, 2013.

[14] Aras, D. A., Rasyid, M. R., dan Umrah, S. "Peran Guru Pendidikan Agama Islam (PAI) dalam Mengimplementasikan Pembelajaran Sifat-Sifat Terpuji Pada Siswa," AL-FIKR: Jurnal Pendidikan Islam, vol. 3 , no. 1, pp. 10-19, 2017.

[15] Amin, A., Wiwinda, W., Alimni, A., dan Yulyana, R. "Pengembangan Materi Pendidikan Agama Islam Berbasis Model Pembelajaran Inquiry Training Untuk Karakter Kejujuran Siswa Sekolah Menengah Pertama,” At-Ta'lim: Media Informasi Pendidikan Islam, vol. 17, no. 1. 